\title{
O ESPÍRITO SANTO CONTRA O FEITIÇO E OS ESPÍRITOS REVOLTADOS: "CIVILIZAÇÃO" E "TRADIÇÃO" EM MOÇAMBIQUE
}

Peter Fry

Em pesquisa recente sobre a religiosidade na cidade de Chimoio, capital da província central de M anica, M oçambique, detectei forte movimento nas igrejas pentecostais, em particular, e protestantes, em geral, contra a feitiçaria e os espíritos malignos do que é chamado de "tradição africana" 1 . A expressão mais radical desse movimento encontrei em uma igreja zionista2, a Igreja Bethlehem de M oçambique, cujo líder, bispo J ohn3, me ofereceu uma interpretação poligenista do livro do Gênesis, postulando que Deus criou negros e brancos separadamente, condenando os primeiros a uma vida assolada pela ambição e inveja, manifestas e operacionalizadas através do feitiço e da ação de "espíritos revoltados". A oposição entre "tradição" e "civilização" fundamenta uma reflexão sobre as causas do sofrimento humano, inclusive a recente guerra civil em M oçambique. A crítica à "tradição" está na base de uma teologia tal hada para "libertar" os cristãos dos males da ambição e da inveja que são os culpados pelos males do país.

Evidentemente, os conceitos de "tradição" e "civilização" são categorias do pensamento social dos meus interlocutores, um tanto distantes da maneira como são utilizados por outros setores - os biens pensants, por assim dizer - da sociedade moçambicana. Para os intelectuais das organizações não-governamentais e setores importantes da I greja Católica, por exemplo, à "tradição moçambicana" é dado um valor positivo, algo que deve ser "respeitado" e "resgatado" da pressão da "globalização". Para eles, os homens e as mulheres adivinhos não são semeadores de discórdia e ódio através dos espíritos e da feitiçaria; são "médicos tradicionais", detentores de "conhecimento indígena". "Civilização" e "modernidade" são, nesse contexto, termos a serem evitados, suspeitos de carregar etnocentrismos nocivos. No mundo social dos agentes do "desenvolvimento sustentável" o conceito de multiculturalismo reina como panacéia para a dramaticamente triste situação pós-colonial. M as os sentidos desses 
conceitos também diferem dos sentidos a eles atribuídos pela sociologia clássica e pela teoria da modernização, por exemplo, onde aparecem carregados de val ores nem sempre explicitados. Por essa razão, portanto, neste ensaio, esses termos serão banidos do meu vocabulário analítico. Meu intuito é entender sua operação como bases fulcrais de uma crítica social.

Começo com a descrição de uma cerimônia religiosa promovida pela Igreja Bethlehem e as circunstâncias em que apareceu a exegese poligenista do livro do Gênesis. Em seguida, passo a arrolar os argumentos utilizados pelos meus interlocutores, cristãos e não-cristãos, para compreender a crítica à "tradição" em favor do Espírito Santo e da "civilização". Esses argumentos expressam uma crítica da concepção da desigualdade social contida na cosmologia nativa, concepção esta baseada na crença de que a felicidade é um recurso limitado e que um ganho para um indivíduo implica, necessariamente, um grau igual de sofrimento para outrem. A família cristã é representada como um modo de vida que permite aos indivíduos um quotidiano e até o enriquecimento livres da cobiça dos outros e de acusações de feitiçaria. Termino meu ensaio, retomando a questão dos limites do relativismo em face da persistência de crenças em racialismo e feitiçaria.

\section{Uma cerimônia para tratar a infertilidade que revela um mito de origem pré-adâmica e poligenista do Homo sapiens sapiens}

Na sexta-feira, 26 de outubro de 1997, o bispo J ohn convidou-me para participar de uma cerimônia na casa do senhor Manuel, dono de uma frota de vans que transporta passageiros entre Chimoio e a cidade de Beira, capital da província de Sofala na costa do Oceano Índico. A cerimônia em questão era para resolver um problema muito sério do dono das vans com a sua mulher: casados há mais de dez anos, ainda não tinham filhos. A causa do problema, explicou-me o bispo, era o "espírito revoltado" de uma pessoa que teria sido morta por um antepassado patrilinear de Manuel ${ }^{4}$. Espíritos zangados desse tipo voltam para afligir (kupfuka) os descendentes dos seus algozes até serem retribuídos, tradicionalmente recebendo uma mulher cujos filhos levarão o seu nome. A igreja do bispo J ohn promete uma solução diferente para esse tipo de problema. A cerimônia, na qual será sacrificado um animal para o espírito vexado, o afastará para sempre.

Chego à casa do bispo em um bairro popular no lado norte da cidade e, logo em seguida, saio com ele, a sua mulher, o juiz da igreja - respon- 
sável pela ordem na instituição - e a esposa. Atravessamos o centro para atingirmos um dos bairros mais imponentes da cidade, onde vivem estrangeiros que trabalham nas organizações não-governamentais e os moçambicanos considerados ricos. Lá pelas dez horas da noite aproximamo-nos da casa imensa de M anuel e entramos por um portão de ferro. Logo somos recebidos com entusiasmo e reverência, sendo convidados a entrar na sala onde são servidos sanduíches e Coca-Cola. Sinal dos tempos, pois a fábrica de Coca-Cola do Chimoio abrira alguns meses antes, indicação tangível do fim da guerra civil que assolou o país de 1980 a 1992 e do socialismo também5.

Fora da casa, a grande área de concreto está se enchendo de gente da igreja, homens, mulheres e crianças. Os anciãos acomodam-se em cadeiras no fundo da área. O bispo senta-se no meio deles, tendo uma pequena mesa à sua frente. Eu sou colocado em uma posição de honra entre o bispo e o juiz da igreja, responsável pela resolução das desavenças entre os fiéis. À nossa direita sentam-se os demais homens, também em cadeiras, enquanto à nossa esquerda as mulheres se ajeitam em esteiras no chão. A maioria dos presentes veste-se com roupas do cotidiano, salvo o bispo, que usa uma batina vermelha amarrada com um cordão, e algumas mulheres, incluindo as mulheres do bispo e do juiz, que usam panos de cor verde ou branca nas cabeças com cruzes vermelhas na frente. No centro da ferradura humana, dois rapazes, em pé, tocam tambores de dois lados pendurados nos seus pescoços. Os membros da igreja dançam ao redor deles. No início, o ritmo cadenciado acompanha uma dança relaxada, quase um andar estilizado em volta dos tocadores. À medida que o ritmo acelera, a dança balanceada torna-se mais acrobática e dionisíaca, os mais jovens pulando cada vez mais alto a cada rodada. A um sinal do bispo, os tambores silenciam, os participantes reassumem os seus lugares e começa a prece coletiva, cada um dirigindo as suas palavras a Deus. De vez em quando, uma ou outra mulher treme, sinal de iminente possessão pelo Espírito Santo. Quando o silêncio volta, um ancião da igreja levanta e pede a leitura de um trecho da bíblia, principalmente do Antigo Testamento, partindo em seguida para a exegese. Assim, ao longo da noite sucedem-se dança, canto, prece e pregação.

Lá pelas 4 horas, um tanto de areia é trazido e colocado no centro do espaço em frente ao bispo que, com seu bastão, forma sete compartimentos, cada um com uma cavidade. A to contínuo, um enorme e fedorento bode é arrastado, contra a sua vontade, para o espaço entre o bispo e o altar de areia. O bispo convoca $M$ anuel e pergunta a razão da cerimônia. M anuel aparenta uma certa perplexidade e permanece sem pala- 
vras. Finalmente, balbucia apenas que está com "problemas". O bispo continua pregando e fala longamente sobre Elisabeth, que, apesar de velha, concebeu um filho. Desta forma, refere-se elipticamente ao "problema" de Manuel.

Nesse momento, os donos da casa são chamados para o centro, entre o altar e a mesa do bispo, onde seguram o bode pelos chifres. O bispo corta o pescoço do animal. Enquanto isso, um ancião lê o Levítico 3, 12, que descreve como deve ser sacrificado um bode:

“12. M as, se a sua oferta for uma cabra, perante o Senhor a oferecerá.

13. Porá a mão sobre a sua cabeça, e a degolará diante da tenda da congregação. Então os filhos de Arão espargirão o seu sangue sobre o altar em redor."

Sinto-me transportado para dentro do Antigo Testamento que parece uma etnografia da situação que observo. O bicho é suspenso sobre o altar de areia e o sangue respinga nos sete buracos previamente preparados. $O$ restante do sangue é despejado em uma bacia de plástico verde e misturado com água e sal. A dança continua, e o canto também, tudo muito bem-humorado. Depois, o superintendente da igreja, auxiliar imediato do bispo, leva uma outra bacia com água, sal, cinzas e sangue. Passa de casa em casa em volta da área, lançando o líquido com a corda que tira da sua cintura. Enquanto isso, o bispo me explica que a corda na cintura espanta os maus espíritos, e é por isso que os padres a usam também. Quando chegamos à casa principal, uma senhora da igreja é dramaticamente possuída por um espírito, que, fico sabendo depois, é do bisavô de $M$ anuel. Interpelado pelo bispo, o antepassado reclama que a casa está sendo muito maltratada por um espírito de madzviti, um soldado do regimento Zulu que conquistou essa zona no século XIX sob o comando de Gungunhane, e que ele teria matado para ficar com a sua mulher ${ }^{6}$. $\mathrm{O}$ bispo acalma o espírito e avisa que estão sendo tomadas as medidas necessárias para o seu apaziguamento.

Em seguida, um fogo é preparado em cima do altar de areia e o leitor retoma o Levítico:

“14. Depois trará dela a sua oferta, por oferta queimada ao Senhor, a gordura que cobre a fressura, sim, toda a gordura que está sobre ela.

15. Os dois rins e a gordura que está sobre eles, e a que está junto aos lombos, e o redenho que está sobre o fígado, juntamente com os rins, ele os trará. 
16. O sacerdote queimará isso sobre o altar; é o alimento da oferta queimada, de cheiro suave. Toda gordura será do Senhor".

O bispo segue os passos da receita bíblica e a fumaça sobe até o céu estrelado. Quando não há mais fumaça, o bispo cobre o restante do fogo com uma lata. O que sobra do bicho vai para as panelas, onde será cozido pelas mulheres e oferecido aos fiéis para compensar essa noite de tanto "trabalho".

No final da cerimônia, o sol já no céu, a família de Manuel instala-se em uma esteira diante da nossa mesa. Os vários anciãos passam atrás, colocando suas mãos nas cabeças de toda a família, falando baixo e tremendo. Uma mulher da casa responde à benção com um forte tremor e cai possuída. A pesar da sua brava resistência, ela é levada para uma das extremidades da área onde o espírito zangado que a possui é mandado embora. Manuel chora e treme, balança sua cabeça como se ele próprio estivesse próximo ao transe, e balbucia "J esus, J esus...".

N esse momento, o juiz vira-se em minha direção e peremptoriamente começa a falar sobre a diferença entre os brancos e os africanos. Ele opina que são os espíritos malignos o grande problema da África, e que a Europa não os tem. Disse eu que tinha. "Sim”, ele retrucou, " mas são bastante mais fracos". Concordo. Ele continua me explicando que Deus tirou a razão e a inteligência dos africanos, mandado-as para a Europa e os brancos, pois o J ardim de Éden estava de fato na África. “O nosso subsoIo", ele fala, "é muito rico, mas não podemos ver. Deus tirou a nossa visão. Estávamos bem, mas pecamos. Estamos a pagar os pecados dos antepassados." O juiz insiste na inferioridade dos negros apesar de todos os meus esforços para convencê-lo do contrário. Pergunta se um africano já tinha inventado algo como um avião e, como prova do seu argumento, comenta que a volta dos portugueses é muito positiva, pois sabem gerir negócios. Não era que a fábrica têxtil, que após a Independência e durante a guerra civil tinha quase parado a sua produção, estava funcionando novamente graças à volta do senhor Magalhães, seu antigo gerente português? A tribui todos os males da M oçambique pós-colonial ao fato de os portugueses terem sido “corridos" do país na época da Independência, em 1975. Não adianta o meu esforço para oferecer outras explicações, como as secas terríveis e a guerra fratricida patrocinada pela África do Sul durante toda a década de 80. Meu interlocutor mantém sua posição. Insiste em que a pobreza e desorganização da África se devem à "tradição" africana: o ciúme, a inveja, a feitiçaria e os espíritos zangados. "Vocês se ajudam. Nós não conseguimos nos ajudar", são as suas palavras finais e definitivas. 
Depois disso, os anciãos e eu somos chamados para dentro da casa principal, onde a mesa está fartamente coberta de arroz, galinha assada e bode ensopado. Fico espantado com a quantidade de arroz que os meus amigos parecem querer comer. Eu aceito muito, mas mesmo assim comentam que é pouco. Tudo é regado à Coca-Cola. Em seguida, voltamos exaustos para as nossas casas.

\section{A exegese do bispo}

Alguns dias depois, em uma visita à sua casa, perguntei ao bispo mais detalhes sobre o que o juiz havia me dito. Em primeiro lugar, ele confirmou que o J ardim de Éden estava de fato localizado na África. Leu o Gênesis 2.10-14 e disse que dos quatro rios que saíam do J ardim, o Gihon é o rio Zambesi e o Tigirisi é o rio Limpopo. Tudo bem perto! M as também afirmou, com brilho nos ol hos, que as diferenças entre negros e brancos estavam escritas no livro do Gênesis. Quando respondi que não me lembrava de nenhuma referência à cor das pessoas que Deus criou, o bispo me deu a sua bíblia e me mandou ler do Gênesis 1.26 em diante:

“27. Assim Deus criou o homem à sua imagem, à imagem de Deus o criou, macho e fêmea os criou.

28. Deus os abençoou e Ihes disse: Frutificai e multiplicai-vos; enchei a terra, e sujeitai-a. Dominai sobre todos os peixes do mar; sobre todas as aves dos céus e sobre todos os animais que se arrastam sobre a terra."

E fui lendo até chegar aos versos 7 e 8 do segundo capítulo:

“7. Formou o Senhor Deus o homem do pó da terra, e soprou-Ihe nas narinas o fôlego da vida, e o homem tornou-se alma vivente.

8. Ora, plantou o Senhor Deus um jardim no Éden, ao oriente, e pôs ali o homem que tinha formado."

Quando atingi o Gênesis 2.22, onde Deus criou Eva da costela de Adão, o bispo ordenou que eu me detivesse e lançou um olhar triunfante. Mas tive de confessar que ainda não entendia o que estava tentando me mostrar. $M$ andou-me ler de novo. $E$ de novo. $E$ ainda não percebia. Finalmente, o bispo perguntou-me: “Então, Deus não criou os homens duas vezes? Não foi que criou o homem (Gênesis 1.26) e depois criou Adão e Eva no J ardim de Éden (Gênesis 2.8 e 21-25)?". A pesar dos meus 
protestos sobre a falta de evidência, o bispo insistiu que os primeiros a serem criados foram os negros, enquanto Adão e Eva foram os primeiros brancos. Em seguida, perguntou-me quem era a serpente. Quando não consegui responder, ele explicou com a satisfação de quem é mestre da lógica e da verdade que a serpente simbolizava os primeiros homens negros que sabiam muito bem se multiplicar. O homem negro levou uma criança no colo para mostrar a Eva. Ela, curiosa, queria saber como fazer uma coisa tão bonita. $\mathrm{O}$ homem negro/serpente ensinou-a. Em seguida, Eva ensinou A dão e os dois foram expulsos do J ardim por um Deus furioso. O primeiro filho de Eva, Caim, fruto da sua primeira experiência sexual com um homem negro, nasceu, evidentemente, "misto", mulato. O segundo, A bel, branco. O primeiro foi sovina e ofereceu um sacrifício pequeno a Deus (o bispo utilizou o termo "cerimônia", evocando os ritos religiosos contemporâneos africanos), enquanto seu irmão $A$ bel foi generoso. Deus favoreceu o segundo, que foi morto pelo irmão mulato por ciúme. Rejeitado e expulso pelos pais, Caim saiu para morar com os negros, parentes do seu genitor. Seus descendentes são os profetas. Em seguida nasceu Seth que, mantendo relações sexuais com as suas irmãs, se tornou o antepassado de todos os brancos.

O mito relatado pelo bispo me foi contado como uma história verdadeira que torna inteligível a situação atual do mundo. Esse mito é, como diria Malinowski, uma "carta" que explica e legitima a ordem social vigente. Portanto, é como tal que devemos compreender a estória que conta. Mas, como qualquer mito, a exegese do bispo é uma elaboração a respeito de um tema universal, ou seja, a relação entre a vida e a morte, entre os que passaram e os que vivem. Como tal, ela é construída sobre uma série de oposições binárias: Deus/homem, vida/morte, homem/muIher, branco/negro, forasteiro/autóctone e assim por diante. A estrutura do mito transmite, portanto, mensagens não tão conscientes sobre a estruturação das vidas intelectual e social do seu contador e seus ouvintes. E, finalmente, como uma bricolagem de noções, relações e idéias que perpassam a longa duração das sociedades africanas em contato com as sociedades européias, a exegese excita curiosidades filogenéticas. Lançando mão de todas essas dimensões, espero poder entender pelo menos parte do seu significado genérico e da sua relevância contemporânea.

O bispo revelou-se um poligenista de longa linhagem. No século $X V I$, Paracelso sugeriu que os indígenas das ilhas americanas descendiam “de outro A dão," enquanto Giordano Bruno “atribuiu ao gênero humano três grandes antepassados, Enoque, Leviatã e Adão, sendo este último o procriador apenas dos judeus, que assim se tornaram o grupo 
humano, a 'raça' mais jovem" (Poliakov 1974:106). No século XVII, o campeão da teoria pré-adâmica foi La Preyère, a quem Poliakov descreve como um criptojudeu francês que, em 1655, publicou Systema Theologicum ex Preadamitaram Hypotesi, argumentando que os brancos eram descendentes de A dão, mas que as outras "raças" tinham uma origem anterior a Adão. De acordo com Poliakov, o livro causou sensação e ganhou adeptos. La Preyère foi preso por suas opiniões heréticas e confessou o seu erro, tendo declarado: “Um católico que compreende a necessidade de seguir a opinião geral dos santos padres evita o perigo de se perder." (Cohen 1980:12).

M as a exegese bíblica do bispo introduz inovações importantes em relação à versão de La Preyère. Em primeiro lugar, os primeiros habitantes do mundo são os negros, criados para "multiplicar". Os primeiros brancos, A dão e Eva, são assexuados. Desta forma, a história do bispo reitera as velhas e batidas representações coloniais sobre a "Iascívia sexual" dos africanos em contraste com o controle sobre o sexualidade que seria uma suposta característica dos seus colonizadores. M as na história do bispo, são os negros sexuados a fonte da perda da inocência de Eva. Os negros, detentores do conhecimento do sexo, em aliança (literalmente) com a primeira mulher branca (é ela quem efetua a mediação entre os autóctones e os forasteiros), são também causa da ira de Deus e da expulsão dos brancos do J ardim de Éden, que, como vimos, se situava na África Austral. Fica implícito que são esses mesmos brancos que muito tempo depois vão voltar para o lugar da sua origem para dominar os homens primordiais mediante a sua técnica e organização social superiores.

M as o mito contado pelo bispo contém ainda outro elemento inovador em relação aos pré-adâmicos europeus: a paternidade de Caim que, sendo o primeiro filho de Eva com a "serpente" negra, é de cor "mista". A dão é o seu pater, mas não o seu genitor. São os mulatos que carregam a maldição de Caim e também a proteção de Deus, pois sobrevivem e são da linhagem dos profetas. Tentador é reconhecer nessa parte do mito a ambivalência que caracteriza as representações sobre os "mistos" na atualidade em M oçambique. "Assimilados" à cultura dos seus pais brancos, não deixam de ser vistos como marcados pela herança materna africana, homens e mulheres intersticiais das duas "culturas" e das duas "raças". Sua ambivalência ou ambigüidade coloca-os simbolicamente em um lugar apropriado para os poderes mágicos e a profecia, como também no lugar da trapaça e da malandragem do seu suposto antepassado Caim.

O discurso poligenista do bispo zionista sugere uma predestinação racial inexorável e, portanto, sem remédio. Na sua prática social, porém, 
o bispo é um fervoroso anti-racista e várias vezes caracterizou o protestantismo como um protesto contra o racismo da Igreja Católica no período colonial, quando manteve os negros em posição subordinada sem acesso aos escritos sagrados. Penso, portanto, que a sua versão do Gênesis deve ser entendida apenas como uma versão particularmente radical da crítica social à inveja e à ambição desenfreadas manifestas na suposta prática da feitiçaria.

\section{A extensão social do mito}

Durante a minha convivência com a África, acostumei-me a ouvir brancos expressarem os seus pontos de vista sobre as supostas diferenças entre eles e os negros. Na África do Sul, a Igreja Holandesa Reformada contribuiu para a ideologia do apartheid com um outro mito bíblico, o da maldição de Cam. De acordo com a exegese de Edmund Leach no seu já clássico ensaio Genesis as Myth (Leach 1969), Cam foi amaldiçoado pelo seu pai, Noé, quando este descobriu que este seu filho mantivera relações sexuais com ele enquanto dormia após uma bebedeira. O negro Cam e seus descendentes foram condenados a serem sempre os servos dos descendentes dos seus irmãos brancos, J apheth e Shem ${ }^{9}$. Esta foi a primeira vez, porém, que ouvira um mito bíblico enunciado por um africano negro. M as não foi a primeira vez que ouvira outras comparações entre negros e brancos idênticas às que escutara com regularidade dos brancos do apartheid na África do Sul e da segregação rodesiana. Por várias vezes durante as minhas estadas em $M$ oçambique fui testemunha de comentários do tipo "nós negros não prestamos". Por mais que argumentasse em sentido contrário, muitos interlocutores insistiam em que os brancos não eram assolados pela bruxaria, pela feitiçaria e pelos curandeiros. Enquanto os brancos cooperavam entre si, alegavam, os negros, consumidos pela ambição e pela inveja, se destruíam mutuamente através das armas materiais e/ou espirituais à sua disposição.

Evidentemente, este ponto de vista não é geral em M oçambique e tampouco uniforme no campo religioso propriamente dito, e por isso se torna necessária, antes de prosseguir, uma breve pincelada sobre esse campo, resumindo o que já coloquei em artigo anterior (Fry 1998b).

No centro da cidade de Chimoio, na "cidade de cimento", há dois edifícios religiosos imponentes: a catedral católica em estilo neogótico suburbano, de um lado, perto da sede do governo e dos bancos; e uma mesquita enorme com quatro minaretes em verde e branco, do outro, na 
zona mais comercial. Faz sentido. O catolicismo era a religião oficial do Estado antes da Independência, enquanto o islamismo era, e continua sendo, a religião dos descendentes de indianos, a maioria comerciantes ${ }^{10}$. Nos "bairros", ou seja, nas zonas que se espalham a partir da cidade de cimento em infinitas ruelas de chão batido, entre casas de construção "tradicional" na sua maior parte, encontra-se uma quantidade enorme de pequenas igrejas e mesquitas de vários tamanhos, estilos e nomes. $O$ Departamento de Assuntos Religiosos do Ministério do Interior forneceume uma lista com 84 igrejas formalmente registradas, mas o número é, obviamente, bem maior. No cinema da cidade instalou-se a brasileira "Deus é Amor". Invisíveis são as miríades de "curandeiros" e "profetas" que, à exceção do escritório da Associação dos M édicos Tradicionais de M oçambique, preferem não se exibir publicamente.

No interior do campo religioso distingue-se, primeiro, entre quem "reza" e quem "não reza". Os últimos são considerados como aqueles que continuam no mundo da "tradição" dos "curandeiros" (madzinganga), embora deva ser dito que, na prática, a fronteira não parece tão clara assim. Entre os que rezam há uma divisão fundamental entre cristãos e muçulmanos. São mundos à parte e mutuamente estranhos.

Entre os cristãos distingue-se, primordialmente, os "católicos" dos "protestantes". Entre os protestantes há três categorias básicas: os "históricos", como os anglicanos e metodistas, onde o Espírito Santo não se manifesta; os pentecostais, onde o Espírito Santo apenas se manifesta; e os "espiritualistas", onde o Espírito Santo se manifesta e "profetiza". É nesta última categoria que se encontram os zionistas da Igreja Bethlehem de M oçambique. Os mazione, como são chamados localmente, são os descendentes de um movimento religioso que surgiu na África do Sul no início do século XX com a chegada de um missionário americano da Igreja Cristã A postólica em Zion localizada em Chicago. Milenarista nas suas origens, com ênfase na cura através do exorcismo, o movimento zionista proliferou entre os trabalhadores negros da África do Sul mediante um processo de sucessivas fissões que resultou na formação de múltiplas igrejas autônomas. Trabalhadores migrantes moçambicanos, ao voltarem para o seu país, introduziram o movimento em M oçambique. Embora antitradicionalista, no sentido de combater os males da feitiçaria presente e passada, ele é considerado pelas outras igrejas como o que mais incorporou elementos religiosos "tradicionais", como o uso de tambores, a dança e a profecia através da possessão⒈

Levando em conta essas categorias mais amplas, cada igreja se define em relação às outras por uma série de sinais diacríticos constituídos 
por sua "disciplina" (murairo), que se refere basicamente a regras de vestimenta e àquelas concernentes à alimentação, ao casamento e à medicina. Pertencer a uma igreja implica, sobremaneira, obedecer a essas regras. A "dureza" da disciplina aumenta com a distância da Igreja Católica, que é vista como a mais tolerante de todas. Mas, também, o rigor da disciplina aumenta, entre os protestantes, dos "históricos" em direção aos mais "espiritualistas". Vi um ou outro metodista bebendo cerveja, por exemplo. M as os pentecostais, como no Brasil, evitam bebida, tabaco, espetáculos etc. Os "espiritualistas", como os zionistas, bastante orientados pelo A ntigo Testamento, acrescentam também as proibições do Levítico, próprias aos judeus e muçulmanos. J ohn reconhece que a disciplina da sua igreja é muito dura, o que afugenta os crentes com menos perseverança.

É importante frisar que a diferenciação religiosa em Chimoio corresponde, grosso modo, à diferenciação socioeconômica da população. A Igreja Católica é associada ao establishment ${ }^{12}$, as igrejas protestantes históricas com pessoas mais letradas e bem-sucedidas economicamente, enquanto as igrejas espiritualistas parecem recrutar seus membros entre as pessoas mais pobres e menos escolarizadas.

A racialização das diferenças culturais dramatizada no mito de origem enunciado pelo bispo zionista era mais pronunciada nas igrejas protestantes "espiritualistas" do que nas igrejas que mais se aproximavam do mainstream evangélico. Nestas, como certas A ssembléias de Deus, por exemplo, a ênfase recai na cultura. Os pastores dessas igrejas criticavam não os "negros" ou "africanos" em si, mas "os nossos usos e costumes" ou a "tradição africana". Ao falar em “tradição" referiam-se à feitiçaria e aos curandeiros.

Vale aqui lembrar que a posição crítica em relação aos curandeiros coloca todas as igrejas protestantes em contraste com a Igreja Católica, que é acusada de simplesmente tolerar (ignorar) tudo que acontece fora dos seus muros. De fato, os intelectuais sucessores da teologia da libertação cultivam ativamente a "tradição africana", através da noção de "inculturação", em forte contraste com o rigor de certos setores da Igreja no período colonial, como os franciscanos, por exemplo. Essa "tradição africana", ao contrário da "tradição" dos pentecostais, ignora a feitiçaria em favor dos rituais de solidariedade como ritos de passagem, o conhecimento da natureza e expressões artísticas como dança e música.

A crítica à "tradição africana" encontra-se, portanto, mais explícita nas igrejas pentecostais, que em anos recentes têm proliferado exponencialmente na África Austral, em geral, e em M oçambique, em particular. 
Portanto, compreender o significado da crítica à tradição implica entender o imenso apelo das igrejas pentecostais de todos os matizes em Chimoio.

O desafio, logo, e aqui me vejo inspirado pela tese recente de Clara M afra (1999), é achar interpretações que levem em consi deração o alastramento global das igrejas pentecostais e a sua especial ressonância em cada local particular. Organizo meu argumento baseado naqueles dos próprios moçambicanos que, membros ou não de uma ou outra igreja cristã ou seguidores do islamismo, refletem constantemente sobre o fenômeno do crescimento das igrejas protestantes, especialmente os pentecostais e os neopentecostais. M inha tarefa é "traduzir" a própria reflexão moçambicana para uma linguagem mais ou menos condizente com a tradição da antropologia e acrescentar dados para ressaltar ou questionar a plausibilidade de cada uma dessas interpretações.

Elas são de três tipos. A primeira, que denomino de "funcionalista", atribui a força das igrejas à necessidade que a população sente de viver em "comunidade" após a desintegração social provocada pela guerra civil. A segunda, a "manipulativa", atribui o sucesso das igrejas à esperteza e ambição política e econômica dos pastores e bispos. A terceira interpretação é estritamente teológica e parte de dentro do campo protestante. Argumenta que o Espírito Santo é mais poderoso que todos os outros espíritos e que somente ele pode aliviar eficaz e permanentemente o sofrimento humano.

\section{A interpretação funcionalista}

O crescimento das igrejas protestantes e pentecostais é interpretado aqui como uma resposta à necessidade dos agentes sociais de construírem redes de solidariedade e de se agarrarem a valores novos para enfrentar a desintegração ocasionada pela guerra civil que terminou apenas em 1992.

A intenção da política socialista do governo da Frente para a Libertação de M oçambique (Frelimo) a partir da Independência, em 1975, foi modernizar o país no espaço de dez anos. Isto seria feito mediante a nacionalização dos meios de produção e, nas áreas rurais de economia de subsistência, através da construção de "aldeias comunais". Ao mesmo tempo, Iançou-se uma acirrada campanha contra o capitalismo, o colonialismo e a "tradição". Os chefes tradicionais foram substituídos por jovens membros do partido organizados em Grupos Dinamizadores. Os curandeiros eram reprimidos como expoentes do "obscurantismo". Obs- 
curantistas eram também os cristãos e muçulmanos, que, embora tolerados, sofreram bastante restrições à sua liberdade de ação13. Em princípio, cristãos praticantes não poderiam ser membros do Partido da Frelimo, o que os afastou do acesso ao poder e das benesses do regime socialista. Embora seja fácil exagerar o efeito concreto dessas políticas na vida social, não há dúvida que elas tiveram um impacto tão grande quanto as dos colonialistas que os antecederam. Elas também foram centradas na "conversão" dos africanos à cultura européia via uma política de assimilação, mas, ao reconhecerem que esse processo seria longo, seus idealizadores se acomodaram efetivamente com o que chamaram de "usos e costumes" africanos, que tiveram que tolerar em nome da governança possível.

A ideologia e a prática da Frelimo procuravam solapar as instituições "tradicionais" no sentido de criar um "homem novo" em uma sociedade nova. Tiveram, contudo, pouco tempo para provar sua eficácia, pois logo em seguida à Independência um movimento guerrilheiro, a Resistência $\mathrm{N}$ acional M oçambicana (Renamo), iniciou uma brutal guerra de guerrilha contra o governo da Frelimo. Formada por um grupo de dissidentes da Frelimo e apoiada pelo governo racista de Ian Smith da Rodésia, a Renamo começou sua carreira sabotando a luta pela libertação do Zimbabué. Quando a Rodésia se tornou Zimbabué em 1980, a Renamo foi "herdada" pelas forças de segurança da África do Sul, que viam nela o caminho mais rápido para a destruição do governo da Frelimo. Nessa época de Guerra Fria, a Renamo procurou legitimar suas atividades afirmando atuar em nome da democracia. A té o final da década de 80 , a guerra tinha tomado conta de quase todas as zonas rurais de M oçambique. Somente as cidades e sedes dos distritos estavam nas mãos do governo e estas se incharam com milhares de refugiados. Dezenas de milhares de pessoas foram mortas em combate, enquanto outras centenas de milhares morreram de fome e de doenças a ela associadas. Cerca de 4 milhões de uma população de 15 milhões de indivíduos estavam refugiados nos países vizinhos e outros tantos tinham buscado santuário nas cidades. Uma grande parte da infra-estrutura de transportes foi aniquilada, as escolas e as clínicas médicas nas zonas rurais foram quase todas destruídas e a renda nacional chegou a níveis mais baixos que antes da Independência.

No dia em que foi assinado o acordo de paz de Roma, em outubro de 1992, a guerra cessou por completo. Com o fim das hostilidades, o processo de reconciliação entre as partes foi rápido e bem-sucedido, surpreendendo até os mais otimistas. Milhares de refugiados retornaram para suas aldeias, a atividade econômica foi retomada, as missões católicas voltaram a funcionar e as igrejas protestantes começaram a prolife- 
rar. É nessa relação entre a paz e a vitalidade da vida religiosa que os "funcionalistas" baseiam os seus argumentos. A ruptura dos laços de parentesco e das instituições "tradicionais" de ajuda mútua teria produzido a necessidade de estabelecer valores e instituições sociais alternativos.

Outro argumento dos funcional istas, elaborado sobretudo por antigos frelimistas, é que a inadequação dos serviços de saúde e a miséria generalizada exacerbada pela política neoliberal do governo pós-socialista produzem a "necessidade" de procurar formas alternativas de cura e de resolução de problemas.

\section{A manipulação}

A interpretação mais cínica da expansão das igrejas protestantes é que ela se deve à manipulação inescrupulosa por parte de pastores e bispos de uma população "ignorante" e facilmente iludível. Advém, sobretudo, de dentro da Igreja Católica, de alguns quadros da Frelimo e de al gumas lideranças muçulmanas, ainda não conformados com a derrota do "socialismo científico" e do seu monopólio sobre o pensamento correto. Não são apenas os não pentecostais que atribuem a alguns pastores e bispos uma cínica manipulação; dentro do pentecostalismo não faltam acusações mútuas de manipulação religiosa para fins escusos.

\section{"Eficácia cosmológica"}

A explicação mais generalizada que os pentecostais e espiritualistas me deram para a popularidade de suas igrejas é que o poder do Espírito Santo, sendo maior que o de todos os demais espíritos, é capaz de vencêlos definitivamente. Basta acolher o Espírito Santo e obedecer as regras da igreja para se tornar imune à feitiçaria e aos espíritos "malignos" ou "revoltados".

Para entender este ponto, torna-se necessária uma breve discussão sobre as interpretações de infortúnio de acordo com o que se chama de "tradição". Aqui estamos em terreno movediço. O que é "tradição" para alguns não é para outros. É um termo cujos sentidos são contestados em uma sociedade que agora, mais do que nunca, põe indivíduos que antes viviam em comunidades culturais e lingüísticas relativamente homogêneas em situações sociais altamente diferenciadas. M esmo assim, um conjunto de preceitos e práticas comanda um consenso bastante amplo. 
Em primeiro lugar, nenhum infortúnio é fortuito. A cosmologia "tradicional" oferece explicações para o "como" e o "porquê" da cada evento, para utilizar os termos de Evans-Pritchard. Hoje em dia, a ciência ocidental acrescentou muito às respostas de como ocorre um infortúnio, mas é a cosmologia local que, ao mesmo tempo, exige e providencia uma resposta ao porquê de cada evento particular. Como em todas as cosmologias africanas, a aflição é sempre atribuída a algum mal-estar nas relações sociais, incluindo vivos e mortos. A penas raramente é uma doença ou morte atribuída à vontade do Criador. Cada aflição provoca, portanto, uma reflexão sobre as relações sociais do sofredor no sentido de achar uma explicação possível. Em seguida, visita-se um adivinho que, por intermédio do espírito que o possui ou de um aparato físico de adivinhação, se pronuncia sobre as causas em questão. M uitos adivinhos podem ser consultados para confirmar o diagnóstico ou para achar a explicação que mais convém aos consulentes.

Para cada aflição há uma miríade de causas possíveis, mas as mais comuns que encontrei resultam da bruxaria, da feitiçaria ou da vingança espiritual. Acredita-se que a feitiçaria é empregada por um inimigo movido pela inveja, ciúme ou desejo de enriquecer. Acredita-se que a inveja leva os indivíduos a desejar o mal para os seus inimigos. Este desejo, em si, é capaz de trazer aflição para a pessoa invejada, sobretudo se o invejoso possui um espírito de feitiçaria (shai yo uroyi), o que corresponde à noção de bruxaria entre os Azande, um poder como que inato ao indivíduo. As bruxas (varoyi) encontram-se à noite para matar e comer a carne humana. M as, assim como entre os Azande, as pessoas de Chimoio reconhecem que qualquer um pode causar danos às pessoas que inveja através da feitiçaria que pode ser praticada por intermédio de um adivinho (nganga). Há diversos mecanismos que um nganga pode recomendar, mas em todos os casos o preço pago pelo mandante é muito alto. Sacrifícios regulares são necessários para que o feitiço não volte para atacar o seu controlador, causando doença ou até a morte do mandante ou de um parente próximo.

O uso da feitiçaria não é provocado apenas pela inveja. Trata-se de uma arma importante para responder a uma outra emoção, a ambição de enriquecer. De novo, há várias maneiras de agir, mas a mais comum é se apossar do espírito de uma pessoa morta. Este espírito pode ser "comprado" de um curandeiro ou pode ser adquirido pela pessoa ambiciosa que, para tanto, precisa matar alguém, de preferência um parente próximo, através de feitiço. $O$ espírito em questão demanda sacrifícios regulares sem os quais fica "revoltado", trazendo sofrimento para o seu controlador e seus parentes. Depois da morte do assassino ou comprador de espíritos, a "dívida" é herdada pelos seus descendentes que serão castigados 
com doença e morte pelos espíritos dos mortos até o pagamento da retribuição. Foi essa a causa atribuída à esterilidade de Manuel e de sua mulher que encontramos no início deste ensaio e que fora revelada pelo Espírito Santo através de uma das mulheres da Igreja Bethlehem.

A retribuição, como mencionei acima, era efetivada no passado mediante o oferecimento de uma mulher para o espírito em questão, com quem ela efetivamente se casava. Essa mulher nunca se casa convencionalmente, mas mantém relações sexuais com quem quer, os filhos levando o nome do morto. Dessa forma, o morto e a sua linhagem são compensados pela morte de um dos seus membros, que foi impedido, ele próprio, de gerar filhos. Essa contabilidade revela a lógica da economia política do sistema social pré-colonial, baseado na acumulação de riqueza e poder através da acumulação de esposas que contribuíram com a sua força de trabalho para a produção de alimentos e com a sua fertilidade para a produção de filhos. Hoje em dia, com a crescente monetarização da economia, a mulher pode ser substituída por uma soma de dinheiro que, em princípio, deve ser utilizada para obter uma mulher para a linhagem ofendida como esposa para o homem morto.

$M$ as a guerra civil recente também aumentou o perigo que vem dos antepassados zangados. No caso do dono das vans no início deste ensaio, a aflição dele e da sua esposa fora atribuída à ação de um soldado de Gungunhane, morto pelo antepassado de Manuel para roubar a sua mulher que invejava. Ou seja, os vivos estão ainda se acomodando às maldades cometidas há mais de cem anos. A guerra civil entre a Renamo e a Frelimo é muito mais recente, mas as oportunidades que apresentava para assassinatos motivados por rixas pessoais e por inveja fizeram com que haja agora uma multidão de espíritos zangados, prontos para exigir retribuição dos vivos. De acordo com o nganga Benedito, os espíritos dos mortos dessa guerra recente já começaram a provocar doenças e outros sofrimentos para obter retribuição. A reconciliação pós-guerra não exclui a eventual retribuição pelos males cometidos, não através dos tribunais, mas sim dos espíritos dos mortos que, mais dia, menos dia, exigirão sua justa recompensa dos vivos. A guerra, então, não apenas causou morte e desintegração social, ela colocou em marcha um processo de ajuste de contas que levará tanto tempo para ser efetuado quanto a guerra de Gungunhane. Deixou os que sobreviveram perigosamente expostos à vingança daqueles que foram mortos pelos seus parentes ${ }^{14}$.

Há, portanto, na base desse sistema, uma contabilidade de longo prazo na qual as colunas do bem e do mal deverão, cedo ou tarde, se contrabalançar. Como disse o bispo J ohn: 
“A pessoa faz o mal para conseguir o bem. Se todos fossem maus, não haveria bom, haveria só mau. Se todos fossem bons, haveria bons, não haveria problemas. Esta diferença é a origem. É como entrevistar as pessoas: quem matou pessoa, há de apanhar a razão é boa para ele, ou porque queria arrancar um dinheiro para cuidar dos filhos, sempre há um motivo que provocou uma, e esse motivo é para beneficiar alguém. [...] Todo o bem que faz é mal para o outro. É por causa disso que ele quando promove uma equipe de músicos, é boa coisa porque é diversão, aparecem adversários. Você promove uma equipe de boxe aparecem adversários, você pode fazer bem com toda vontade, mas o seu bem é mal para o outro. Se você andar bem vestido na rua é mau para o outro. É mau, É mau. Andar bem vestido é mau, andar mal vestido é mau."

Para o senhor Benedito são apenas os adivinhos que podem resolver todos esses problemas. Os homens e as mulheres das igrejas, porém, não concordam. Eles argumentam que os adivinhos nunca poderão apaziguar os espíritos revoltados definitivamente. Não há como garantir, segundo eles, que a pessoa assassinada, ela própria, não teria assassinado uma outra pessoa cujo espírito poderá mais tarde também exigir retribuição, não da linhagem do assassino, mas do assassino do assassino. É como se cada dívida resolvida revelasse apenas mais dívidas a serem saldadas seguidamente e sem fim. Dessa forma, os vivos nunca podem se livrar dos atos dos seus antepassados. Além disso, acusam os adivinhos até de inventarem espíritos malignos para poderem aumentar as suas receitas. O bispo J ohn insiste que, além de ser mais eficaz, o cristianismo custa muito menos!

De acordo com os cristãos, as aflições resultantes da feitiçaria e da cobrança de dívidas de curta e longa durações só podem ser resolvidas, definitivamente, pela ação do Espírito Santo. Mais poderoso que todos os outros espíritos, só ele pode garantir a permanente imunidade dos vivos da vingança dos mortos ofendidos e do feitiço dos vivos. Para que o Espírito Santo possa atuar nesse sentido, o indivíduo deve se filiar a uma igreja, juntando-se à "família de Cristo".

O bispo J ohn e todos os protestantes deixam claro que a conversão a uma igreja protestante de qualquer matiz, implica uma radical reorientação da vida. O fiel é obrigado, primeiro, a rejeitar a "tradição", ou seja, cerimônias para os antepassados e visitas aos adivinhos. Em seguida, ele deve "entrar para a família de Cristo", freqüentando várias reuniões por semana e contribuindo regularmente com seu dízimo. Nesta "Família de Cristo", o que impera são as leis cristãs reveladas pela palavra de Deus 
escrita primeiro por M oisés e, mais tarde, pelos apóstolos. A lei e a noção de pecado tornam-se fundamentais, e vários pastores comentaram comigo que foi a vinda da palavra de Deus que trouxe a concomitante responsabilidade dos indivíduos.

\section{Reflexões analíticas}

Tendo enumerado as interpretações dos meus interlocutores de Chimoio sobre a guerra dos cristãos contra a "tradição", cabe agora avaliá-las à luz das minhas próprias observações.

Em primeiro lugar, não há como negar que a interpretação funcionalista tem lá os seus méritos. A final, as igrejas são de fato comunidades funcionais, oferecendo, sim, apoio intelectual, social e emocional para os seus adeptos. M as esta interpretação, como qualquer interpretação funcionalista, não consegue dar conta das razões para essa forma muito específica de sociabilidade. Além disso, não há como negar que, apesar de a engenharia social e ideológica da Frelimo e, sobretudo, a destruição promovida pela guerra terem trazido uma desintegração social sem precedentes, a solidariedade social antiga não foi de todo destruída. Redes de parentesco continuaram a providenciar caminhos de fuga e de ajuda mútua; grupos religiosos reduzidos a semiclandestinos continuaram a funcionar. Além disso, e apesar das investidas contra o "obscurantismo", as calamidades de cada um continuaram a ser compreendidas em termos das ações dos espíritos e do feitiço. Os relatos que colhi sobre a experiência de guerra se referem a uma miríade de disputas pessoais mais do que a uma batal ha campal entre exércitos e ideologias. Como entender por que tanta gente opta pela "família de Cristo" quando as redes de parentesco ainda existem e podem sempre ser ativadas? Vale aqui ressaltar que o convite pentecostal à conversão não oferece para o novo adepto uma família que não possui; oferece uma família a mais.

O raciocínio também funcionalista de que as pessoas procuram explicações "místicas" para suas doenças por falta de hospitais e médicos é o famoso e batido argumento de faute de mieux para explicar a produção de formas "não racionais" para a resolução de infortúnio. O que essa interpretação não leva em conta é que, do ponto de vista da maioria de moçambicanos, a ciência médica ocidental nunca foi e não é vista como alternativa às interpretações e remédios "espirituais" oferecidos pelas igrejas e pelos curandeiros. Como os Azande, a grande maioria dos moçambicanos com quem me encontrei lança mão de dois modos de 
interpretação. M esmo se M oçambique tivesse uma rede de hospitais capaz de atender a toda a população, as instituições oferecendo interpretações e resoluções "espirituais" de cada aflição continuariam incólumes. Basta olhar para o Brasil.

A interpretação cínica da manipulação só pode ser levada a sério caso se negue qualquer senso crítico da população como um todo. Foi contra o argumento do africano ignorante facilmente enganado por adivinhos, profetas e líderes políticos sem escrúpulos, utilizado com cansativa freqüência pelos detratores das culturas colonizadas, pelos missionários, administradores e políticos, que muito da antropologia do período colonial se desenvolveu. Evidentemente, o alastramento de um movimento religioso não podia ser compreendido em termos do voluntarismo de profetas cínicos. A antropologia funcionalista inglesa, por exemplo, demonstrava a coerência das crenças e a sua estreita relação com a "estrutura social". O carisma de líderes religiosos derivaria da sua capacidade não de enganar os seus seguidores, mas de captar os anseios destes e formulá-los em um idioma condizente com a sua experiência cultural. Basta pensar nas análises de Peter Worsley (1968) dos cargo cults, de Ernest Gellner (1969) sobre os profetas Bérberes e do historiador Terence Ranger (1967) sobre os médiuns Shona que articularam a rebelião contra os primeiros colonizadores da Rodésia em 1896-97. No meu estudo sobre o nacionalismo cultural no final do regime colonial na Rodésia, argumentei que os médiuns que incorporavam os antepassados efetivamente transformaram vox populi em vox dei (Fry 1976). M eus interlocutores nunca colocaram em questão as premissas da cosmologia nativa, mas, como os Azande, não eram crédulos a ponto de aceitar qualquer interpretação dos seus infortúnios, apenas aquelas que pareciam social e politicamente plausíveis.

Essa perspectiva não nega, de fato, a existência de manipulação. Afinal, não tenho dúvidas de que muitos profetas e adivinhos mais bemsucedidos são bastante conscientes dos mecanismos em jogo. Lembrome de Quesalid, por exemplo (Lévi-Strauss 1963). Hoje em dia, com a explicitação "científica" das técnicas de persuasão, creio que as possibilidades de manipulação consciente aumentam. Embora não haja nenhuma prova cabal da utilização de "modernas" técnicas de persuasão pela Igreja Universal do Reino de Deus, por exemplo, não faltam indícios fortes de que estas existam. M as como essas técnicas também se baseiam em um conhecimento prévio da "vox populi", concluo que a presença ou não da manipulação consciente e cínica não é rel evante para uma interpretação do alastrar do conjunto das igrejas pentecostais. Nesse sentido, 
a interpretação em termos de manipulação também teria que dar conta da relação entre o discurso das igrejas e os contextos sociológico e cultural dos seus membros.

Se as interpretações em termos das supostas funções das igrejas ou da manipulação cínica dos pastores não são suficientes para dar conta do fenômeno que descrevo, temos que levar a sério a interpretação cosmológica, que aponta para o poder superior do Espírito Santo sobre a “tradição".

Em primeiro lugar, é preciso aprofundar um pouco mais a caracterização da natureza da "tradição" que é representada na fala dos cristãos e dos outros. $N$ as acepções do senhor Benedito e na fala quase estruturalista do bispo J ohn, é como se se tratasse de um jogo de soma zero. A felicidade humana é finita. $O$ bem de um é o mal do outro. Para cada ganho por parte de um indivíduo há uma correspondente perda por parte de um outro proximamente ligado a ele. Para ambos, portanto, as representações que têm a respeito da "tradição" se assemelham muito às que Foster desenvolveu para o que ele chama de "sociedades de privação" (deprivation societies), onde comportamentos invejosos são particularmente aparentes. Sociedades de privação seriam aquelas caracterizadas não por pobreza simplesmente ou pela ausência de recursos materiais e do poder a eles associados, "mas antes a sociedades nas quais al gumas pessoas são pobres enquanto outras não o são, e nas quais o bem-estar e poder daqueles que têm muito é visível para, e ressentido por, aqueles que têm pouco" (Foster 1972:168). Sociedades de privação, em particular sociedades camponesas, são caracterizadas, ainda segundo Foster, pela "imagem do bem limitado", "enquanto sociedades em que a vida é vivida como um jogo de soma zero, no qual a vantagem de um jogador é sempre à custa do outro" (Foster 1972:168). Continua:

“O ponto importante nessas sociedades é que todos os recursos - todas as coisas boas da vida - são vistos como constituindo um sistema fechado, finito em quantidade do ponto de vista do grupo, incapaz de expansão ou crescimento. Conseqüentemente, toda vantagem obtida por um indivíduo ou família é vista como uma perda para outros, e a pessoa que obtém aquilo que o mundo ocidental lauda como 'progresso' é encarada como uma ameaça à estabilidade de toda a comunidade. [...] Nessas sociedades a saúde social é concebida como baseada na pobreza compartilhada, um delicado equilíbrio no qual as posições relativas devem mudar o mínimo possível. Embora em sociedades de jogo de soma zero qualquer um que possua comida, saúde, filhos e algum bem-estar material seja invejado, esta inveja é 
agravada quando uma destas duas situações se desenvolve: (1) alguém, ou alguma família, se eleva significativamente acima da média, ou (2) alguém, ou alguma família, cai significativamente abaixo da média" (Foster 1972:169).

A situação que descrevo se assemelha menos às sociedades camponesas e mais a um outro locus das "sociedades de privação" apontado por Foster, nomeadamente segmentos de sociedades complexas que estão e sentem que estão em desvantagem em relação a outros segmentos.

\footnotetext{
“Ao longo da história, os camponeses têm aparecido como os que vivem em privação por excelência, mas um comportamento similar parece caracterizar a vida no gueto, em sociedades indígenas norte-americanas, comunidades de 'chicanos', campos de prisioneiros de guerra e outras situações nas quais pessoas em privação sabem que são discriminadas” (Foster 1972:168).
}

M as há uma diferença importante entre a situação que descrevo e as observações de Foster. Em primeiro lugar, as pessoas com quem conversei não se sentem discriminadas, e certamente não o são pelos brancos que representam uma parcela muito pequena da população. Em segundo lugar, não sou eu quem identifica um jogo de soma zero: são os próprios protestantes negros. São eles - e não o anal ista - que produzem a crítica à "tradição", construindo uma oposição entre as representações que têm dos "brancos" e dos "negros", entre o que eles chamam de "civilização" e "tradição".

Resta agora tentar indagar sobre o porquê da plausibilidade dessas representações. Em primeiro lugar, não há dúvida de que não é nenhuma coinci dência as representações dos protestantes negros de Chimoio e os velhos preconceitos dos seus antigos colonizadores. Da mesma forma que a exegese do bispo é de longa linhagem, assim também são as representações sobre o "misticismo" dos africanos. Além disso, a "assimilação" à civilização portuguesa foi a política oficial dos governos moçambicanos pelo menos da virada deste século em diante. E, como vimos, a Frelimo deu continuidade a esta política, combatendo o "obscurantismo" e encorajando a guinada para a "modernidade" na sua versão socialista (Cabaço 1995).

Mas, argumentar que os meus interlocutores de Chimoio apenas reproduzem idéias "hegemônicas", por assim dizer, não procede, sobretudo porque outras idéias radicalmente diversas também estão disponíveis e porque conferiria pouca reflexividade a eles. Seria, afinal, uma explicação muito simplista! M eus interlocutores também foram expostos a outras idéias sobre "raça", não menos do que ao radical anti-racismo 
da Frente para a Libertação de M oçambique. Samora Machel insistia sempre nessa postura anti-racista, incentivando a população a combater o colonialismo e o imperialismo, e não os brancos como tal. M ais recentemente, surge também em M oçambique um forte nacionalismo cultural, que prega os valores da "tradição" como contraponto a um desenvolvimento pautado no neoliberalismo promovido a partir do Consenso de Washington.

A vitalidade da postura antitradicionalista deve ser interpretada, portanto, em termos da avaliação que os meus interlocutores fazem da situação em que vivem, avaliação esta evidentemente construída a partir dos conceitos e argumentos disponíveis. Em primeiro lugar, parece que a transição da "tradição" para a "civilização" representa a celebração da ideologia individualista associada por Louis Dumont às sociedades modernas ocidentais.

Como vimos, dentro do protestantismo, as aflições não serão mais interpretadas em termos da micropolítica familiar e atribuídas à maldade alheia, mas em termos dos pecados do próprio sofredor que é considerado responsável pelo êxito ou não da sua vida. Os múltiplos inimigos da "tradição", como os feiticeiros e os espíritos revoltados, são reinterpretados como emissários de um único inimigo, o demônio. Os múltiplos amigos da "tradição", ou seja, os antepassados, cedem lugar a um único poder protetor, Deus e o Espírito Santo. A conversão a uma igreja como a do bispo J ohn implica uma radical reorientação da vida. O fiel é obrigado a comparecer a várias reuniões por semana, a contribuir regularmente com seu dízimo e a obedecer à "disciplina" ou "doutrina" da igreja à qual pertence. A credita-se que quem obedece às regras se imuniza contra as ações do demônio, ou seja, contra a ambição e inveja alheias e contra a ira dos espíritos dos mortos. Segue que o infortúnio é agora interpretado não apenas em termos da micropolítica do sofredor, mas também, e sobretudo, pela sua incapacidade de observar as regras da sua igreja. O seu infortúnio é interpretado como punição de Deus. O que as igrejas oferecem, portanto, é um santuário seguro contra a inveja e o ódio, contra o feitiço e os espíritos, enfim, libertação, como dizem os pastores, dos males da "tradição".

A interpretação cosmológica do êxito do protestantismo em Chimoio parece, portanto, ser uma interpretação também sociológica, pois propõe a supremacia do "indivíduo" autônomo, íntegro e responsável sobre a "pessoa" da "tradição". Propõe a supremacia de leis universais de explicação da distribuição da felicidade e do sofrimento no mundo sobre o particularismo da "tradição". No protestantismo, esse "indivíduo" como ser único e autônomo sofre ou é feliz dependendo da sua capacidade de seguir a "doutrina" da sua igreja, doutrina esta que é compartilhada com todos 
os outros membros da "família de Cristo". Na "tradição", a felicidade e o sofrimento resultam do estado das relações sociais que o indivíduo como "personalidade social" (Radcliffe-Brown 1965) mantém com seus familiares vivos e mortos e com seus vizinhos e outros conhecidos. Evidentemente, portanto, a "tradição", que enfatiza o particularismo da micropolítica das pessoas, opõe-se logicamente à "civilização" das igrejas, que ressalta o universal ismo da relação do indivíduo com a "doutrina" da sua igreja.

$M$ as essa interpretação em si não basta. Como vimos, o sofrimento do senhor $M$ anuel e da sua esposa foi atribuído às conseqüências não da sua desobediência às regras da igreja, mas das ações de um antepassado patrilinear. M esmo se é verdade que há uma ênfase forte na responsabilidade de cada indivíduo de garantir o seu bem-estar através da sua adesão aos ensinamentos da sua igreja, é também verdade que esta adesão em si não é suficiente para precavê-lo contra os efeitos retardados dos pecados dos antepassados patrilineares. Por mais que a igreja do bispo J ohn pregue a luta contra a "tradição", a primeira se encontra sempre à mercê da última. A "tradição" continua rondando os indivíduos, lembrando-os sempre que também são pessoas portadoras de responsabilidades decorrentes dos grupos de parentesco corporados aos quais pertencem. A realidade do poder dos antepassados não é nunca colocada em questão, e tampouco são os indivíduos aliviados da responsabilidade advinda de sua filiação linhageira15.

Efetivamente, portanto, a viagem para a "família de Cristo" não representa um rompimento com a família de origem do indivíduo que continua pai, irmão, marido, primo, trabalhador etc. Tampouco a conversão ao protestantismo representa um rompimento definitivo com as crenças da "tradição", pois o demônio se manifesta justamente através da feitiçaria e dos espíritos revoltados. Ou seja, o demônio nada mais é que a ambição e a inveja que são constitutivas das relações sociais primárias do indivíduo em questão transportadas para um plano em princípio universalista. Se é verdade que as igrejas combatem os males da "tradição", é também verdade que atestam a sua vitalidade. Como os pastores enfatizaram, trata-se de uma guerra, e uma guerra sem fim.

\section{Reflexões finais}

É lugar comum na antropologia que as viagens de pesquisa deveriam provocar mudanças no autoconhecimento do pesquisador. Gostaria, portanto, de terminar este artigo com uma breve reflexão, que espero desen- 
volver com mais profundidade em trabalhos futuros, sobre os dilemas das metáforas raciais no mundo contemporâneo e sobre o status social e epistemológico da feitiçaria.

As afirmações sobre a superioridade da cultura dos brancos abalaram-me profundamente. Foi difícil acreditar no que estava ouvindo depois de tanto sofrimento com a guerra de Independência que visava livrar o país do racismo. Além disso, doeu ouvir opiniões que pareciam idênticas às dos próprios colonizadores sobre os "usos e costumes" dos africanos, em particular a feitiçaria. Doeu tanto que pensei seriamente em suprimir tudo.

M as com o tempo, fui percebendo que assistia apenas a mais um exemplo da concepção de conhecimentos e práticas como se fossem "propriedades" de uma ou outra "raça", transmitidas através do "sangue". Fui obrigado a deduzir que a autodepreciação racial obedecia à mesma lógica racialista que a autopromoção. A mbos os procedimentos atestam a vitalidade do racialismo apesar do anti-racismo secular da antropologia moderna e das ideologias anti-racistas dos movimentos de descolonização. As ideologias racistas são muito mais fortes e arraigadas que a razão que as contesta.

No que diz respeito à religião e à feitiçaria, fui obrigado a reconhecer não apenas a minha descrença na capacidade de agentes sociais de ferir ou matar os seus inimigos através de métodos "sobrenaturais", como o meu igual desgosto pela idéia de que possam tentar fazê-lo. De fato, esse desgosto veio inicialmente das minhas pesquisas sobre umbanda, macumba e candomblé na década de 70, quando logo percebi que embora os trabal hos exegéticos clássicos (ver, p. ex., Bastide 1961; Santos 1993) dêem pouca atenção à teoria e à prática da feitiçaria, ela é parte fundamental de todas essas denominações ${ }^{16} \mathrm{e}$, como mostra magistralmente Yvonne Maggie (1992), da sociedade brasileira como um todo. Na época, argumentava que as crenças em feitiçaria não "expressam" simplesmente tensões sociais e a insegurança dos indivíduos; elas também as propulsionam. Ao fornecerem razões de sobra para se ver em cada infortúnio a maldade al heia, el as constituem uma verdadeira "cosmologia da paranóia" (Fry 1998a).

Em artigo sobre um violento movimento contra feiticeiros conduzido por padres da Igreja Católica entre os Lele da República do Congo, Mary Douglas levanta exatamente essa questão. Vale a pena citá-la extensivamente:

“A crença em feitiçaria não é rara; ao contrário, é comum nas religiões africanas tradicionais, em países islâmicos ou cristianizados, bem como no cha- 
mado Terceiro Mundo. Entre os antropólogos, afirma-se que rejeitar algo tão central como a feitiçaria significa impor sub-repticiamente, sobre o povo que se pretende estudar, as crenças que sustentam a nossa própria cultura. A té mesmo a descrença na capacidade do feiticeiro de causar dano revelaria um desrespeito de fundo, uma falha na objetividade. A questão força-me a explicar e justificar minha descrença. Não coloco em dúvida a possível existência de magos e feiticeiros, nem mais nem menos do que a de anjos, almas imortais ou demônios, mas duvido que feiticeiros tenham poderes sobrenaturais autônomos capazes de ferir ou matar terceiros. E, pessoalmente, não acho justo que alguém seja processado por um malefício do qual não existe nenhuma prova possível. M inhas simpatias são liberais e emergem em favor daqueles que são acusados (quase sempre com má intenção) de terem feito coisas impossíveis; estes, normalmente, não têm meios de provar sua inocência. E não é uma boa estratégia argumentar que essas pessoas estão sendo acusadas de coisas fisicamente impossíveis de realizar, pois a própria impossibilidade é tomada como mais uma prova de seus poderes ocultos." (Douglas 1999:7-8)

Mas que antropologia é essa que Mary Douglas critica?

Nos primórdios da colonização e da antropologia social, quando ainda era possível pensar em sociedades e culturas relativamente autônomas e integradas, as crenças em feitiçaria eram analisadas como sistemas de interpretação coerentes (Evans-Pritchard 1978) com importantes funções sociais: de manter a "boa moral", de expressar as tensões sociais (Marwick 1970; Turner 1957). Os primeiros administradores coloniais e missionários acreditavam que as crenças em feitiçaria minguariam perante a ciência e a religião ocidentais. Não tardou muito, porém, a constatação de que a crença em feitiçaria era muito resistente. Os antropólogos, a partir do trabalho pioneiro de Evans-Pritchard entre os Azande, acharam uma explicação bastante convincente. Argumentavam que a ciência e as crenças em feitiçaria não entravam em contradição porque respondiam a perguntas distintas. A ciência, assim como o senso comum, procura dar conta do "como" dos eventos, enquanto as crenças em feitiçaria explicam o "porquê" dos mesmos. Em outras palavras, a ciência fala de taxas e a crença em feitiçaria em “incidência”. A partir da noção de situação social que foi enunciada por Evans-Pritchard e que assumiu uma importância ainda maior nos trabalhos da Escola de M anchester, argumentavase que a "modernidade" da ciência e a "tradição" da feitiçaria poderiam facilmente coexistir na África contemporânea sem que isso tivesse qualquer efeito significativo sobre os indivíduos ou a sociedade. Os indivíduos 
lançariam mão das crenças em feitiçaria para compreender a incidência de eventos desagradáveis, mas empregariam a "ciência" como profissionais e cidadãos. É como se os dois sistemas de pensamento ocupassem compartimentos mentais estanques sem que um contaminasse o outro. $O$ sofrimento decorrente do medo do feitiço e das acusações de feitiçaria aparecia apenas nas análises dos cíclicos movimentos de caça aos bruxos e feiticeiros que surgiriam como mecanismos homeostáticos para restaurar o equilíbrio anterior quando a feitiçaria parecia escapar do controle.

A crítica à feitiçaria que constatei entre os membros da igreja do bispo J ohn e outros protestantes de Chimoio sugere que, para eles ao menos, a feitiçaria não possui função positiva nenhuma e que as instituições "tradicionais", longe de poder controlá-la, têm o efeito perverso de exacerbá-la, já que cada caso resolvido apenas revela um outro a ser equacionado e assim por diante. Mas eles não colocam em questão a realidade da feitiçaria; antes pelo contrário. O que prometem é uma solução definitiva para os seus efeitos, sem, e isso é muito importante, lançar mão de acusações contra supostos feiticeiros, como fizeram os padres da Igreja Católica entre os Lele. O movimento protestante ganha adeptos pela sua promessa de enfrentar o mal da feitiçaria mediante um projeto de adesão às regras cristãs que garantem a proteção do Espírito Santo e a solidariedade social das igrejas. Nesse sentido, a "modernidade" das igrejas não coloca em questão a realidade da "tradição"; apenas se apresenta como uma forma mais eficiente e definitiva de se resguardar contra as demandas dos mortos por retribuição e de se proteger dos inimigos que não deixam de lançar mão da feitiçaria. Esta acepção de "modernidade", posta como antítese da "tradição", parece ser, de fato, uma interpretação do cristianismo a partir da lógica básica da própria "tradição". A tensão entre interpretações universalistas e particularistas para o infortúnio existe, portanto, não apenas entre cristãos e curandeiros, mas dentro das próprias igrejas. M ais que um movimento definitivo de um paradigma (a "tradição") para outro (a "civilização"), a conversão a igrejas como a do bispo J ohn representa uma acomodação entre uma e outra onde a universalidade do Espírito Santo está no seu maior poder em relação às demais forças espirituais.

Mas o problema persiste. Um leitor atento a uma versão anterior deste ensaio observou que o meu mal-estar estava ligado nem tanto às duas aversões (à feitiçaria e ao racismo), mas talvez à relação entre elas. "Afinal, como lutar contra a 'tradição' quando ela encarna a crença na feitiçaria, sem com isso reproduzir o discurso racista dos brancos?" 17. Isto só é possível quando se percebe a feitiçaria e a cultura em geral não como propriedades "genéticas" de "raças". Esta é a posição da antropologia, 
mas não, evidentemente, do bispo J ohn e, tampouco, dos intelectuais católicos que mantêm a relação entre "raça" e "cultura", adotando uma versão mais aceitável, por assim dizer, da "tradição africana", onde se enfatiza os aspectos "positivos" como ritos de passagem, ignorando por completo a feitiçaria. O mal-estar, então, está na contradição no mundo contemporâneo entre duas crenças irreconciliáveis: a crença do antropólogo no fundamento social daquilo que é considerado natural pelos "nativos", e a crença muito mais disseminada de que formas de conhecimento são propriedades inerentes de "raças". Algumas igrejas que visitei, e sobre as quais não tenho espaço para tecer considerações neste artigo, têm efetuado uma cisão entre "raça" e "crença", distinguindo claramente não entre negros e brancos, mas entre os cristãos e os outros. N estes casos, o Espírito Santo deixa de ter cor e raça! M as em todo caso, tanto entre os "culturalistas" como entre os "racialistas", há um amplo consenso sobre o valor da "civilização" cristã como o lugar das regras universais e da solidariedade. Quem dera que fosse.

Recebido em 10 de fevereiro de 2000

Peter Henry Fry é professor de antropologia da Universidade Federal do Rio de J aneiro. Autor de, entre outros, Spirits of Protest, um estudo do papel dos médiuns no Zimbabué antes da guerra de libertação, e Para Inglês Ver, uma coletânea de ensaios sobre a cultura brasileira. Está no momento conduzindo trabalho de campo em M oçambique e desenvolvendo pesquisa acerca da representação dos negros nos meios de comunicação brasileiros.

\section{Notas}

1 Agradeço à Fundação Ford pelo financiamento desta pesquisa, ao Arquivo do Patrimônio Cultural de Moçambique que me apoiou ao longo da minha estada em Chimoio e aos muitos bispos, pastores, profetas e curandeiros que me deram o seu tempo de setembro de 1997 a janeiro de 1998. Agradeço também a oportunidade de discutir algumas destas idéias com Omar Thomaz e seus alunos no Cebrap. Evidentemente, eles não têm nenhuma responsabilidade pela minha análise. 
2 As igrejas denominadas zionistas surgiram na África do Sul a partir do início do século $X X$ com a chegada de um missionário americano da Igreja Cristã A postólica em Zion sediada em Chicago. Milenarista nas suas origens, com ênfase na cura através do exorcismo, o movimento zionista proliferou entre os trabalhadores negros da África do Sul mediante um processo de sucessivas fissões que resultou na formação de múltiplas igrejas autônomas. Trabalhadores migrantes moçambicanos, ao voltarem para o seu país, introduziram o movimento em Moçambique.

3 Troquei os nomes dos personagens e das suas igrejas.

4 Nas províncias centrais de Manica e Sofala predomina um sistema de parentesco patrilinear.

5 Logo depois da Independência, em 1975, Moçambique declarou-se um país de orientação marxista-leninista. Em seguida, o governo teve que enfrentar um exército de guerrilheiros, a Resistência Nacional M oçambicana, que, apoiado pela África do Sul, procurava desestabilizar o regime moçambicano em nome da democracia e do capitalismo.

6 Durante o século XIX, o território de M oçambique foi invadido pelo guerreiro Shoshangane que, junto com outros Zulus desafetos do regime de Shaka, rumou para o norte. Gungunhane, neto de Shoshangane, expandiu o controle do seu império de Gaza até a atual província de M anica, estabelecendo a sua capital na atual vila de Espungabeira. Os chefes locais tornaram-se vassalos do imperador. Gungunhane foi preso pelos portugueses na batalha de Chaimite em 1892, sendo em seguida deportado para as IIhas Açores, onde morreu.

7 Nisso jaz uma ironia profunda, pois defendem os antropólogos físicos dos nossos dias que o homo sapiens sapiens, de fato, se originou na África uns poucos milhares de quilômetros ao norte da atual Moçambique e que um pequeno grupo rumou para o norte. Lá, livres das doenças tropicais que evoluíram junto com os primeiros homens e abençoados por um ambiente mais propício, desenvolveram técnicas e formas de organização social que fizeram com que, milhares de anos mais tarde, pudessem voltar para dominar os descendentes daqueles que ficaram na África (Reader 1998). Voltando ao mito, pode-se especular que a expulsão do J ardim de Éden é resultado do conhecimento do sexo oriundo dos negros, que fará com que os brancos possam finalmente voltar para se vingar das causas primordiais de sua queda da graça divina.

8 É interessante especular sobre a relação entre o mulato, intermediário entre os dois pólos branco e negro, e a profecia. De fato, não encontrei nenhuma outra referência a esta relação durante a pesquisa, mas mesmo assim é tentador imaginar uma conexão entre essa categoria intersticial e os poderes mágicos, conexão esta bastante presente na literatura antropológica (Douglas 1966; Turner 1970). 
9 Este mito também apoiava a naturalidade dos estamentos do velho regime francês, Cam sendo o antepassado dos servos, J apheth dos nobres e Shem dos burocratas (Cohen 1980:11).

10 Nas províncias de Niassa, Cabo Delgado e Zambézia, que experimentaram séculos de contato com os comerciantes árabes, o islamismo é compartilhado pela maioria da população.

11 Um padre católico questionou se os mazione são de fato cristãos.

$12 \mathrm{O}$ que não quer dizer que todos os seus participantes são da elite, antes pelo contrário. A Igreja Católica é muito católica neste sentido, agregando mais que as outras igrejas pessoas de todos os segmentos sociais.

13 Há fortes evidências de que haja uma diferença significativa entre o tratamento dado aos católicos e aquele dispensado aos protestantes e muçulmanos. Os primeiros foram mais expostos a toda sorte de perseguições e coações por serem considerados representantes do colonialismo e nunca terem feito o mea-culpa desejado por Samora Machel. Omar Thomaz (comunicação pessoal) confirma esta diferença baseando-se não apenas nos relatos que recolheu entre católicos, mas também nos documentos do Partido da Frelimo (Encontros de 1978, 1982 e 1987) sobre as religiões de Moçambique.

14 Os moçambicanos e os observadores de M oçambique ficaram impressionados com a rapidez da reconciliação após o término da guerra civil entre Frelimo e Renamo. Os mais sagazes sabem, porém, que as contas um dia serão pagas mediante a cobrança dos espíritos revoltados.

15 Uma igreja "espiritualista", porém não zionista, a Igreja dos A póstolos, achou uma solução engenhosa para esse problema. Prega que o indivíduo, ao se converter à igreja, automaticamente converte os seus antepassados, que, por terem vivido antes da chegada da palavra de Deus, não puderam converter-se.

16 Um conceituado pai-de-santo da Bahia, ao receber mais um cliente, comentou "noventa por cento do tempo de um pai-de-santo é gasto em desfazer a maldade alheia." Cada vez que um orixá ou espírito fala comigo prenuncia sobre a minha necessidade de me "proteger". O trabalho de Yvonne Maggie é seminal para essa discussão (Maggie 1992).

17 Observação do parecerista deste artigo. 


\section{Referências bibliográficas}

BASTIDE, Roger. 1961. O Candomblé da Bahia. São Paulo: Companhia Editora Nacional.

CABAÇO, J osé Luís. 1995. A Longa Estrada da Democracia em M oçambique.

COHEN, William B. 1980. The French Encounter with Africans. Bloomington \& London: Indiana University Press.

DOUGLAS, Mary. 1966. Purity and Danger: An Analysis of Concepts of Pollution and Taboo. London: Routledge $\&$ Kegan Paul.

. 1999. "Os Lele Revisitados, 1987: Acusações de Feitiçaria à Solta". Mana, 5(2):7-30.

EVANS-PRITCHARD, E. E. 1978.Bruxaria, Oráculos e Magia entre os Azande. Rio de J aneiro: Zahar Editores.

FOSTER, George M. 1972. “The Anatomy of Envy: A Study in Symbolic Behavior". Current Anthropology, 13(2):165-169.

FRY, Peter. 1976. Spirits of Protest: Spirit-M ediums and the Articulation of Consensus among the Zezuru of Southern Rhodesia (Zimbabwe). Cambridge: Cambridge University Press. . 1998a. "As Religiões Africanas fora da África: O Caso do Brasil". Povos e Culturas, 6:439-471. . 1998b. "Carta de M oçambique". Religião e Sociedade, 18(2):29-42.

GELLNER, Ernest. 1969. Saints of the Atlas. London: Weidenfeld and Nicholson.

LEACH, Edmund. 1969. Genesis as M yth and Other Essays. London: Cape Editions.

LÉVI-STRAUSS, Claude. 1963. Structural Anthropology. New York: Basic Books.

MAFRA, Clara. 1999. Na Posse da Palavra: Religião, Conversão e Liberda- de Pessoal em Dois Contextos Nacionais. Tese de Doutorado, Programa de Pós-Graduação em Antropologia Social, Museu Nacional, UFRJ . MAGGIE, Yvonne. 1992. Medo do Feitiço: Relações entre Magia e Poder no Brasil. Rio de J aneiro: M inistério da J ustiça.

MARWICK, M. G. 1970 [1965]. Socery in its Social Setting: A Study of the Northern Rhodesia Cewa. Manchester: Manchester University Press.

POLIAKOV, Léon. 1974. O Mito Ariano. São Paulo: Perspectiva/Edusp.

RADCLIFFE-BROWN, A. R. 1965. Structure and Function in Primitive Society. New York: The Free Press.

RANGER, T. O. 1967. Revolt in Southern Rhodesia 1896-7: A Study in African Resistance. London: Heinemann.

READER, J ohn. 1998. Africa: Biography of a Continent. Harmondsworth: Penguin Books.

SANTOS, J uanita Elbein dos. 1993. Os Nagô e a Morte. Petrópolis, RJ : Vozes.

TURNER, V. W. 1957. Schism and Continuity in an African Society: A Study of N dembu Village Life. Manchester: M anchester University Press. .1970. The Ritual Process: Structure and Anti-Structure. Chicago: Aldine Publishing Company. WORSLEY, Peter. 1968. The Trumpet Shall Sound: A Study of "Cargo" Cults in Melanesia. London: M acgibbon \& Kee. 


\section{Resumo}

Durante uma cerimônia conduzida por uma congregação zionista em M oçambique, para restaurar a fertilidade de um casal mediante o apaziguamento de um espírito enraivecido, foi-me dito que os brancos eram imunes a este tipo de problema pois estavam livres dos espíritos revoltados e da feitiçaria, sendo portanto mais capazes de cooperar entre si. Tal criticismo da "cultura africana" é disseminado entre muitas igrejas protestantes, em particular os Zionistas e Pentecostais, enquanto a Igreja Católica, através de sua noção de enculturação, tenta manter-se próxima à "tradição africana". $O$ artigo examina os significados ligados à "tradição africana" e suas antinomias, "modernidade" e "civilização, em uma tentativa de demonstrar a ampla distribuição do desejo de controlar os males da feitiçaria e da bruxaria, assim como a inveja e ambição que as movem. $O$ artigo se encerra com uma reflexão sobre a maneira como a análise antropológica falhou em considerar o sofrimento que tais crenças refletem e engendram.

\section{Abstract}

During a ceremony conducted by a Zionist congregation in M ozambique to restore the fertility of a barren couple by appeasing an angry spirit, I was told that whites were immune from these kinds of problems since they were free of angry spirits and witchcraft and more able to co-operate among themselves. Such criticism of "African culture" is widespread among many Protestant churches, in particular the Zionists and Pentecostals in general. Meanwhile, the Catholic Church, through its notion of enculturation, attempts to become closer to "African Tradition". The article examines the meanings attached to "African Tradition" and its antinomies, "Modernity" and "Civilization", in an attempt to demonstrate the widespread existence of a strong desire to control the evils of witchcraft, sorcery, and the jealousy and ambition that move them. The article ends with a brief reflection on the way in which much classical anthropological analysis of witchcraft and sorcery has failed to take into account the suffering that such beliefs reflect and engender. 